\title{
The Epipelagic Fish Community of Beaufort Sea Coastal Waters, Alaska
}

\author{
LAURIE E. JARVELA ${ }^{1}$ and LYMAN K. THORSTEINSON ${ }^{2}$
}

(Received 20 May 1998; accepted in revised form 14 September 1998)

\begin{abstract}
A three-year study of epipelagic fishes inhabiting Beaufort Sea coastal waters in Alaska documented spatial and temporal patterns in fish distribution and abundance and examined their relationships to thermohaline features during summer. Significant interannual, seasonal, and geographical differences in surface water temperatures and salinities were observed. In 1990, sea ice was absent and marine conditions prevailed, whereas in 1988 and 1991, heavy pack ice was present and the dissolution of the brackish water mass along the coast proceeded more slowly. Arctic cod, capelin, and liparids were the most abundant marine fishes in the catches, while arctic cisco was the only abundant diadromous freshwater species. Age- 0 arctic cod were exceptionally abundant and large in 1990, while age- 0 capelin dominated in the other years. The alternating numerical dominances of arctic cod and age- 0 capelin may represent differing species' responses to wind-driven oceanographic processes affecting growth and survival. The only captures of age- 0 arctic cisco occurred during 1990 . Catch patterns indicate they use a broad coastal migratory corridor and tolerate high salinities. As in the oceanographic data, geographical and temporal patterns were apparent in the fish catch data, but in most cases these patterns were not statistically testable because of excessive zero catches. The negative binomial distribution appeared to be a suitable statistical descriptor of the aggregated catch patterns for the more common species.
\end{abstract}

Key words: Arctic, Alaska, Beaufort Sea, epipelagic coastal fishes, fish-habitat relationships, arctic cod, capelin, arctic cisco

RÉSUMÉ. Une étude de trois ans portant sur les poissons épipélagiques habitant les eaux côtières de la mer de Beaufort en Alaska décrit les schémas spatiaux et temporels de la distribution et de l'abondance des poissons et examine leurs rapports avec les caractéristiques thermohalines durant l'été. On a observé d'importantes différences interannuelles, saisonnières et géographiques dans la température et la salinité de l'eau de surface. En 1990, la glace de mer était absente et des conditions marines régnaient, tandis qu'en 1988 et 1991, la glace de mer était épaisse et la dissolution de l'eau saumâtre le long du littoral s'est réalisée plus lentement. La morue polaire, le capelan et les liparis étaient les poissons marins qu'on retrouvait en plus grandes quantités dans les prises, tandis que le cisco arctique était la seule espèce d'eau douce diadrome qu'on retrouvait en abondance. En 1990, la morue polaire âgée de moins d'un an était particulièrement abondante et de taille importante, tandis que le capelan âgé de moins d'un an prédominait durant les autres années. L'alternance de la dominance numérique de la morue polaire et du capelan de moins d'un an pourrait signaler une réaction différente des espèces à des phénomènes océanographiques dus au vent, affectant la croissance et la survie. Les seules captures de cisco arctique de moins d'un an se sont produites en 1990. Les schémas de prises indiquent que les poissons utilisent un vaste corridor migratoire le long du littoral et tolèrent un taux élevé de salinité. Comme pour les données océanographiques, des schémas géographiques et temporaires étaient apparents pour les données des prises de poissons, mais, dans la plupart des cas, ces schémas ne pouvaient être testés sur le plan statistique en raison du trop grand nombre de prises nulles. La distribution binomiale négative semblait être un descripteur statistique approprié des schémas de prises cumulatifs pour les espèces plus courantes.

Mots clés: Arctique, Alaska, mer de Beaufort, poissons côtiers épipélagiques, rapports poisson-habitat, morue polaire, capelan, cisco arctique

Traduit pour la revue Arctic par Nésida Loyer.

\section{INTRODUCTION}

The discovery of petroleum on Alaska's North Slope in 1969 triggered research on fishes inhabiting Beaufort Sea coastal waters in response to concerns about the potential impacts of oil development activities on the indigenous species and their habitats. Most of this work has taken place in the vicinity of Prudhoe Bay, the present center of production activities, and in the waters off the Arctic
National Wildlife Refuge (ANWR). The bulk of the information is based on fyke net and gill net sampling at the shoreline.

The general features of the inshore fish community and its habitats are described in Craig (1984). In early summer, warm $\left(5-10^{\circ} \mathrm{C}\right)$, brackish $(10-25$ practical salinity units [psu]) water resulting from river runoff and ice melt forms an essentially continuous band along the coast. Cold (- 1 to $\left.3^{\circ} \mathrm{C}\right)$, saline (27-32 psu) marine water is present offshore

${ }^{1} 29595$ Rash Road NE, Kingston, Washington 98346, U.S.A.

${ }^{2}$ U.S. Geological Survey, 909 First Avenue, Suite 800, Seattle, Washington 98104, U.S.A.; Lyman_Thorsteinson@usgs.gov

(C) The Arctic Institute of North America 


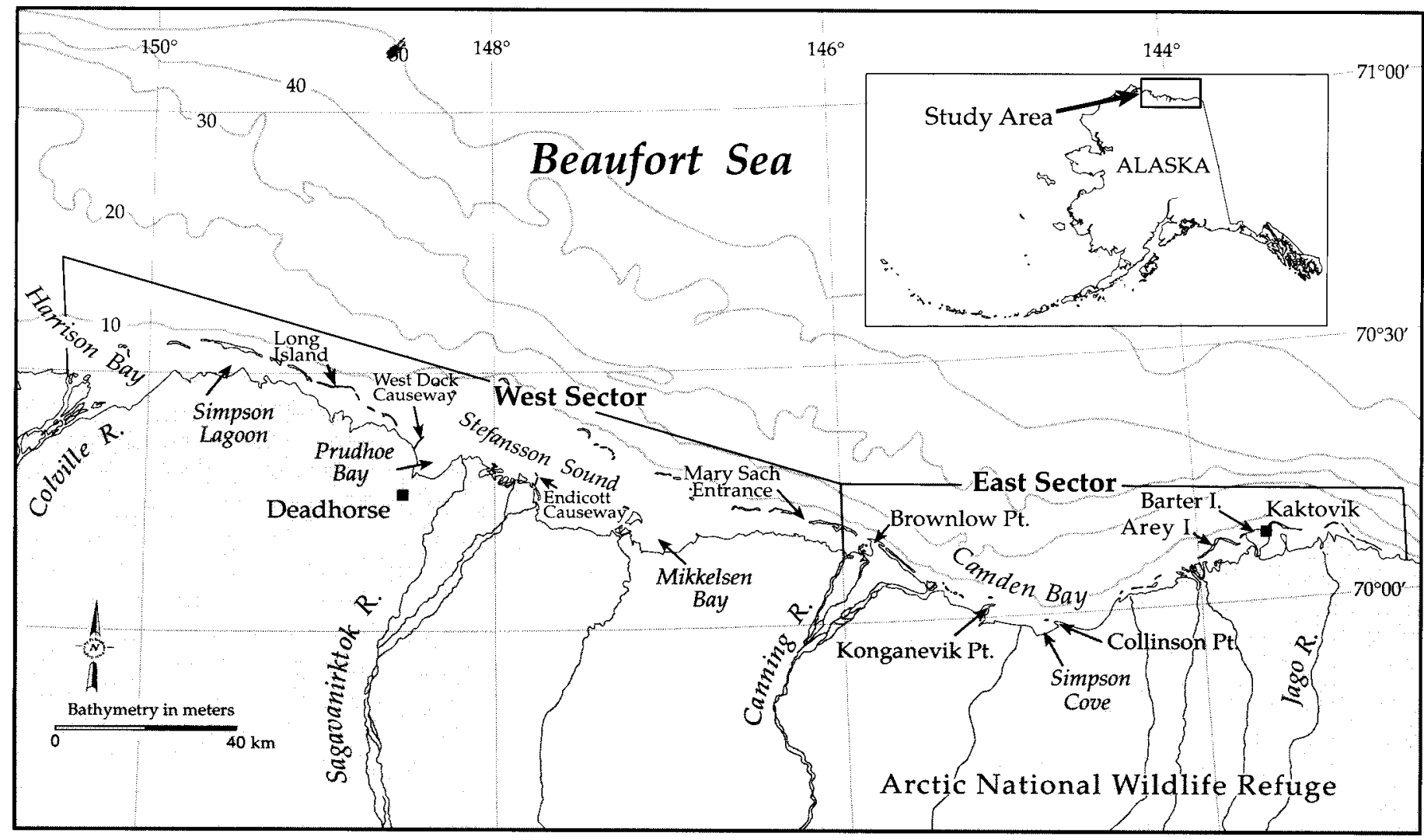

FIG. 1. Beaufort Sea coast, Alaska. Heavy line denotes boundary of study area. Division at $146^{\circ} \mathrm{W}$ longitude is the boundary between west and east sectors. Isobath contours represent depth in meters.

and often underlies the brackish water. Marine water intrusions reaching shallow depth occur during upwelling events caused by east winds. Astronomical tides have comparatively little influence on hydrography, their amplitudes being only about $0.3 \mathrm{~m}$. The brackish water band is progressively eroded during the summer by diminishing runoff and wind mixing.

Marine and diadromous freshwater fishes make heavy use of the brackish water band for feeding. The epibenthic mysids Mysis littoralis and M. relicta and the epibenthic amphipod Onisimus glacialis are the primary prey for most fishes. Over 60 fish species occur in the region; however, only a few are commonly captured inshore. Arctic cod (Boreogadus saida), fourhorn sculpin (Myoxocephalus quadricornis), and arctic flounder (Liopsetta glacialis) are the most abundant marine species. The most abundant diadromous freshwater species are arctic cisco (Coregonus autumnalis), least cisco (C. sardinella), broad whitefish (C. nasus), and Dolly Varden (Salvelinus malma). The freshwater fishes appear to have an affinity for shorelines (Craig et al., 1985).

Offshore fishery investigations in the region are limited. Sampling has been conducted inside and immediately offshore of Simpson Lagoon, using gill nets and Faber nets (Craig et al., 1982). Studies in or near Prudhoe Bay have included investigations of larval fish abundance (Tarbox and Moulton, 1980), arctic cod movements (Moulton and Tarbox, 1987), shallow neritic fish (Houghton and
Whitmus, 1988), and habitat use by juvenile arctic cod (Cannon et al., 1991). In the ANWR area to the east, offshore gill net sampling was conducted in Camden Bay (Fruge et al., 1989; Palmer and Dugan, 1990; Underwood et al., 1992).

In 1988, we initiated a multi-year study of epipelagic fishes in offshore waters intended to complement the inshore investigations underway in the Prudhoe Bay and ANWR areas. The primary goal was to identify broadscale temporal and spatial patterns in the epipelagic fish community of the open-water zone. More specifically, we examined (1) community composition; (2) species' distributions, abundances, and age-length relationships; and (3) species' relationships to habitat attributes during the summer-fall period. This paper presents study results in both regional and broader geographical contexts and indicates directions for further research. Early life history stages are emphasized, as young fish formed the bulk of our catches.

\section{METHODS}

\section{Study Area and Sampling Schemes}

The study area encompassed approximately $250 \mathrm{~km}$ of coastline between the Colville River delta and Barter Island and extended about $30 \mathrm{~km}$ offshore (Fig. 1). It consists of two distinct sectors that differ in coastal 
geomorphology and quantities of river discharge. The west sector extends eastward from Harrison Bay to Flaxman Island, just west of Brownlow Point, and includes Simpson Lagoon and Stefansson Sound. It consists primarily of a shallow $(<10 \mathrm{~m}$ ) lagoon-barrier island environment. Most of Simpson Lagoon is less than $2 \mathrm{~m}$ deep. Several rivers empty into this sector, most notably the Sagavanirktok and the Colville, the largest river in the Alaskan Arctic. The east sector is dominated by Camden Bay and contains predominantly exposed coastline with comparatively deep water (to $30 \mathrm{~m}$ ) near shore. Several small rivers drain into this sector. Our operational definition of 'offshore waters' in this study is waters deeper than $2 \mathrm{~m}$. The distance from the mainland shoreline to the $2 \mathrm{~m}$ isobath varies considerably in the study area; it is relatively small (a few hundred meters $)$ in much of the east sector and large $(>1 \mathrm{~km})$ in most of the west sector.

An $11 \mathrm{~m}$ vessel and a $5 \mathrm{~m}$ skiff were used for setting and retrieving nets. In 1988 we employed a purse seine designed to capture small fish in shallow water. The seine was $150 \mathrm{~m}$ long by $7.3 \mathrm{~m}$ deep, with $19 \mathrm{~mm}$ stretched mesh for the seine's body and $6.3 \mathrm{~mm}$ mesh for the bunt. The net was held across the current in a semicircle for either 10 or 20 min before pursing. The sample consisted of randomly selected stations. Many seine sets were spatially aggregated. However, because of imprecision in position fixes and long elapsed times between sets, each set was considered an independent station. In 1990 and 1991 a surface tow net was used. The net was $11 \mathrm{~m}$ long and had a mouth $6.8 \mathrm{~m}$ wide $\times 1.8 \mathrm{~m}$ deep, tapering to a $0.3 \mathrm{~m} \times 0.3 \mathrm{~m}$ bag. Net panels were of variable mesh size, beginning with $50.8 \mathrm{~mm}$ at the mouth and decreasing to $7.9 \mathrm{~mm}$ at the bag. The net was towed between the two vessels at $0.5 \mathrm{~m} \cdot \mathrm{sec}^{-1}$ for $10 \mathrm{~min}$. Replicate tows were made at all but a few stations. Most stations were arrayed on $\mathrm{N}-\mathrm{S}$ oriented transects; however, opportunistic stations were also occupied during both years. Heavy pack ice prevented access to many transect stations in 1991. Sampling locations were determined by Loran C in 1988, primarily by Global Positioning System (GPS) in 1990, and entirely by GPS in 1991.

In all years, catches were sorted, enumerated, and measured (fork length, nearest $\mathrm{mm}$ ) immediately after capture. In most instances, each fish was processed. However, when large catches of small gadids or capelin occurred, volumetric estimates of numbers were employed. In brief, fish were counted into a small container until it was filled. This procedure was repeated to obtain an average number per container. The total catch was subsequently estimated by multiplying the number of filled containers by the average count per container, then adding any remaining individuals to that total. We typically obtained 50-100 length measurements from large catches of arctic cod and capelin. All Dolly Varden and arctic cisco were measured. Catches of the remaining species were small, and comparatively few measurements were obtained. Most fish were released alive.
Some of the gadid larvae in our catches may have been saffron cod (Eleginus gracilis). Separation of the larval stages of arctic cod and saffron cod entails laboratory examination of differences in pigmentation patterns and other characteristics (Dunn and Vinter, 1984). Saffron cod occur across the North Slope coastal region; however, they have historically composed only a small fraction of the total gadid catches at Prudhoe Bay and Camden Bay (see, e.g., LGL, 1994, Table 8; Underwood et al., 1995, Tables A.1,3,4). Available information on distributions of liparid species (Craig, 1984; Able, 1990) and on seasonal timing of occurrence of their larval stages in the plankton (Dunton et al., 1982; Able et al., 1986) suggests that the liparid larvae we captured were Liparis gibbus and/or L. fabricii.

An Applied Microsystems ${ }^{\mathrm{TM}}$ Seabird CTD-12 conductivity-temperature-depth (CTD) instrument with an internal recording capability was used to obtain thermohaline profiles at stations. The instrument was lowered to within $0.5 \mathrm{~m}$ of the bottom. Upon completion of a cast, data were downloaded to a laptop computer, examined to ensure that the instrument had functioned properly, and stored on diskettes for subsequent processing. The processed depth, temperature, and salinity data are accurate to within $0.1 \mathrm{~m}$, $0.03^{\circ} \mathrm{C}$, and $0.02 \mathrm{psu}$, respectively.

\section{Data Analyses}

Catch data for most of the species were strongly rightskewed, included many zero catches, and had large variance-to-mean ratios. This indicated the catch data might conform to the negative binomial distribution, a statistical distribution often used in analyses of aggregated populations such as schooling fishes. The statistical properties of the negative binomial distribution and ecological applications are described in Poole (1974), Mangel (1987), Welch and Ishida (1993), and Hilborn and Mangel (1997). In brief, the range of the distribution extends from 0 to plus infinity. It has two parameters, the mean, $m$, and the "overdispersion" or "contagion" parameter, $k$. $K$ ranges between zero and plus infinity. When $k$ is very large, the negative binomial distribution approximates the Poisson distribution. Finally, the variance of the negative binomial distribution is always larger than the mean.

Quantitative estimates of the mean-variance relationships of the catch data were obtained by assuming the relationships were approximated by the power function $s^{2}=a \cdot m^{c}$, where $s^{2}$ is the sample variance, $m$ is the sample mean, and $a$ and $c$ are constants. Linear regression of the log-transformed means and variances of catches from replicate tows produced slope estimates that are equivalent to the exponents of the power function. Values of $c$ greater than one are expected if sample variances exceed means.

We calculated expected frequencies of the negative binomial distribution, then tested species' catch data for goodness of fit to the expected distributions by chi-square tests $(\alpha=0.05, d f=f-3$, where $f$ denotes the number of 
frequency classes). Maximum likelihood estimates of the contagion parameter were used in the expected frequency calculations. Frequency classes were pooled when necessary to eliminate empty classes. The minimum frequency in any class was two.

The analyses of catch and oceanographic data were intended to determine whether certain patterns observed during inshore studies prevailed throughout the study area, testing the generalized null hypothesis that oceanographic and biological attributes were invariant in space and time. We examined interannual area-wide variations in catch per unit effort (CPUE), temperature, and salinity during 1990 and 1991. The 1988 data were not included in the among-year tests of CPUE because of differences in gear selectivity. Both temporal and spatial stratifications were used to identify within-year patterns. The temporal stratification was suggested by the rapid seasonal changes of water properties observed in the region (Gallaway et al., 1991, Fig. 14). We divided the sampling time each year into the early period (from start of sampling to 15 August) and the late period (from 16 August to the end of sampling). The spatial stratification was based on the regional differences in coastal geomorphology and river discharge discussed above. The boundary between sectors was located at Flaxman Island. A few tests of variation of fish abundance with distance from shore were also conducted.

We used nonparametric statistical tests (described in Zar, 1996) because the catch and oceanographic data sets were non-normal, and their variances differed. Mean station CPUEs were used as ranking data for tests involving catches. Mann-Whitney U tests were used for two-sample tests, while Kruskal-Wallis one-way ANOVAs and nonparametric multiple comparisons were used for tests of three or more samples. All tests were two-tailed, with $\alpha=0.05$. Since the power of rank sum statistical tests decreases rapidly as data exceed 50\% ties (Helsel, 1990), we did not conduct tests when tied ranks exceeded that value. Many tied ranks occurred in the catch data, mainly as a result of zero catches. Annual mean fish densities were calculated from tow net data by dividing the total species catches by the estimated total volumes sampled.

Length measurements were the primary means of estimating ages and growth rates of fish. Arctic cisco and arctic cod ages were assigned using age-length relationships of fish established by Underwood et al. (1995), which were based on fish collected from ANWR coastal waters in July 1988-91. Arctic cod less than $60 \mathrm{~mm}$ long were assumed to be age- 0 . Capelin larvae were separated from older fish on the basis of both length and body form, which changes dramatically during metamorphosis from larval to juvenile stages. Metamorphosis begins at an age of about 94 days and is completed at about eight months (Leggett and Frank,1990). Post-larvae ages were estimated from age-length data in Bailey et al. (1977). Liparids were assumed to be age- 0 on the basis of their occurrence in the plankton and their size (see Able et al., 1986). Interannual differences in lengths of age-0 arctic cod, capelin, and liparids were statistically tested using our tow net data and 1988 tow net data from Houghton and Whitmus (1988). Mean lengths from large samples $(n \geq 25)$ obtained at stations were used as ranking data for arctic cod and capelin, while samples based on as few as four observations were employed for tests on liparids. Growth rates of age- 0 arctic cod were estimated both by simple linear regression using mean lengths from samples obtained on given dates and from temporal shifts of modes in length frequency distributions. The large number of age- 0 arctic cod length samples obtained during the late period in 1990 also enabled us to examine geographical differences in size during that period.

Average temperatures and salinities in the $0-2 \mathrm{~m}$ stratum (or surface water) were used for all statistical tests that involved oceanographic data because this stratum corresponded to that swept by the tow net.

Univariate analyses of species-habitat associations were not attempted because temperature and salinity were correlated. Instead, associations were qualitatively evaluated in terms of the frequency of species occurrences within water "types" having unique combinations of temperature and salinity ranges. The null hypothesis was that a species used each water type in proportion to its occurrence. Only stations at which the surface water was well mixed $(\Delta \mathrm{T}$ and $\Delta \mathrm{S}<0.5^{\circ} \mathrm{C}$ and $<0.5 \mathrm{psu}$, respectively) were used in the analyses. This screening eliminated 5 stations from the 1990 data set and 14 from the 1991 data set. Finally, the analysis was restricted to the tow net results because interpretation of the seine catch data was usually confounded by the gear having sampled across wide ranges of temperature and salinity in the water column.

\section{RESULTS}

In 1988, seine sampling occurred at 41 stations occupied between 30 July and 3 September (Figs. 2 and 3). Thirty-two CTD casts were made during this period. In 1990 , tow-netting was conducted at 28 stations, 8 of which were occupied on two or more occasions, and 37 CTD casts were made. The sampling occurred between $2 \mathrm{Au}$ gust and 5 September. In 1991, tow net sampling was conducted at 35 stations, 10 of which were occupied more than once, and 47 CTD casts were completed. The sampling took place between 29 July and 2 September.

\section{Habitat Attributes}

Winds were quite variable in direction during 1988 and 1991 (Fig. 4), and sea ice covered much of the study area. In contrast, consistent northeasterly winds prevailed during 1990, and the study area was ice free during the entire sampling period. The interannual differences in meteorological and sea ice conditions produced markedly differing surface water properties (Fig. 5; Table 1). In particular, 1988 and 1991 were characterized by large salinity ranges, 


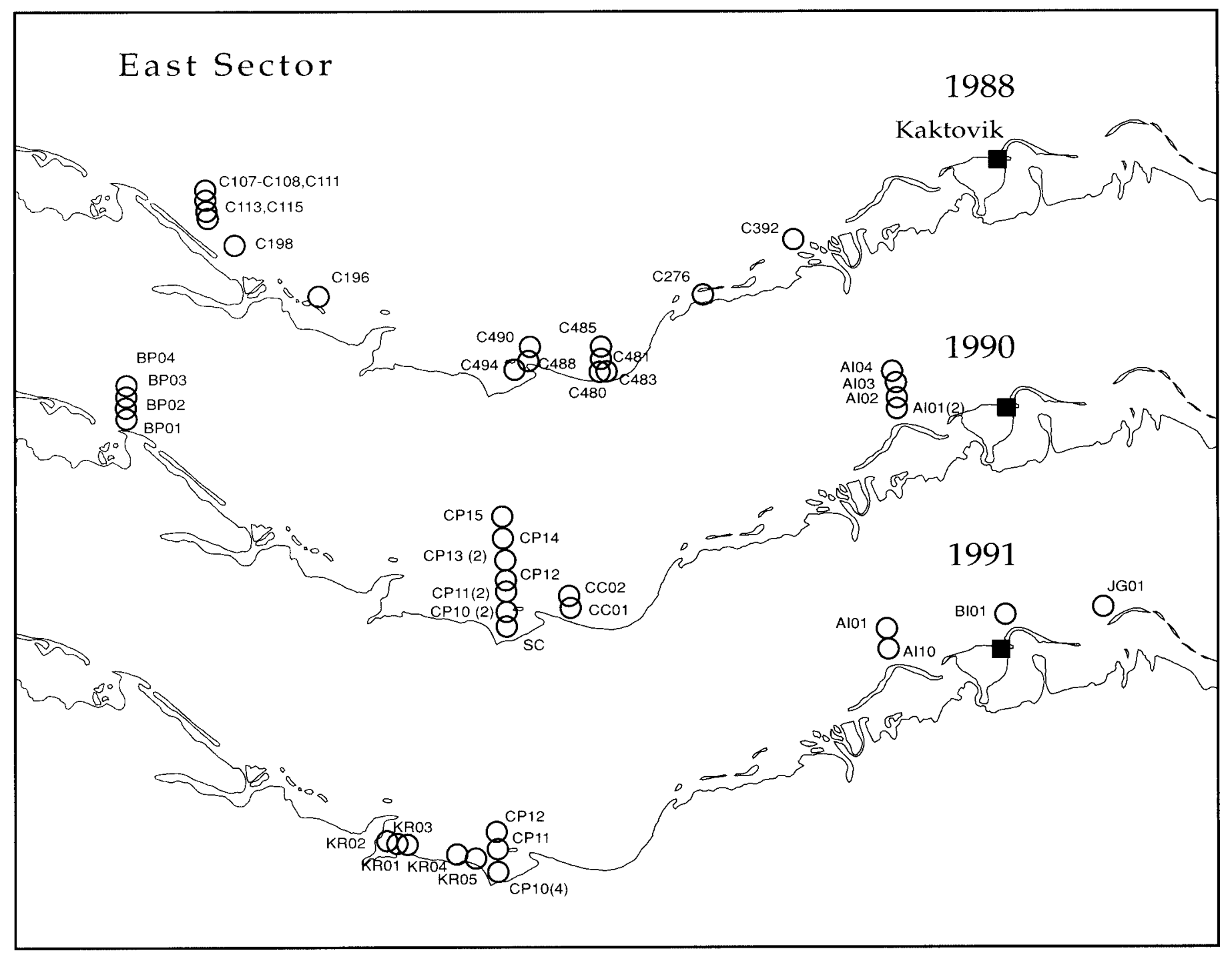

FIG. 2. East sector station locations, 1988, 1990, and 1991. Open circles indicate stations. Numbers in parentheses after alphanumeric station identifiers indicate number of occupations in cases where stations were reoccupied during a summer.

while in 1990 comparatively little variability was evident and surface waters were significantly more saline than in the other years. The below-zero temperatures and associated high salinities in 1988 represent a local upwelling event that occurred in eastern Camden Bay during late August. Interannual surface temperature differences were comparatively small, although temperatures in 1990 and 1991 were significantly different. A general pattern of increasing salinities and decreasing temperatures with advancing season was present in all years, as evidenced by the consistently significant differences in the temporally stratified data (Table 2). The statistical tests of sector differences were less consistent. While west sector temperatures were higher and salinities lower than those in the east sector during 1988 and 1990, the opposite pattern occurred in 1991. The anomalous 1991 results stem from an inequitable distribution of sampling in space and time. Because of pack ice close to shore, we were able to sample in the east sector only during the early period, while the preponderance of sampling in the west sector took place in the late period. CTD data obtained during "shakedown" trials at Prudhoe Bay in late July showed salinities and temperatures similar to those observed in the east sector shortly thereafter.

\section{Catch Characteristics}

Total catches were much larger during the open water year (1990) than during the heavy ice years, when many zero catches occurred at stations (Tables 3 and 4). Also evident were the low species richness and the numerical dominance of arctic cod and capelin in all years. Essentially all of the capelin, liparid, and arctic cisco catches consisted of age-0 fish. Age-0 fish dominated arctic cod catches in 1990 and 1991, when they composed $91 \%$ and $92 \%$, respectively, of the total catch. The size composition of individual catches indicates that arctic cod generally were segregated into discrete size or age groups. During 


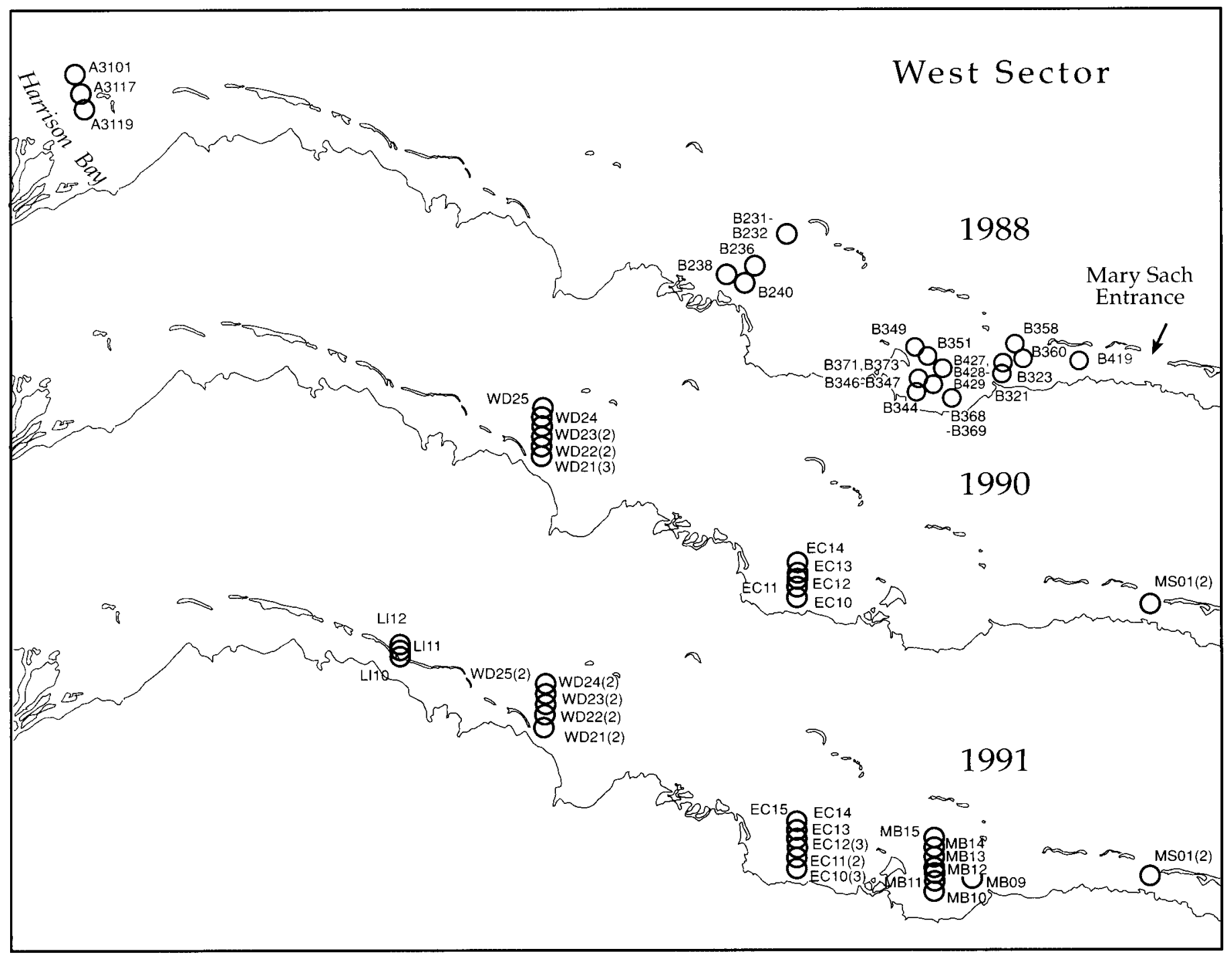

FIG. 3. West sector station locations, 1988, 1990, and 1991. Open circles indicate stations. Numbers in parentheses after alphanumeric station identifiers indicate number of occupations in cases where stations were reoccupied during a summer.

1990 and 1991 , about $73 \%$ and $71 \%$, respectively, of the samples consisted entirely of age- 0 fish, while $7 \%$ and $2 \%$ were composed exclusively of age-1 and older fish.

A few large catches of capelin and arctic cod during the late period constituted most of the annual catch in each year. Larval liparids were relatively abundant and widespread in 1990; however, most of the liparid catch (291 fish) was obtained at one station in the east sector during the late period. The only captures of age- 0 arctic cisco occurred during 1990, when the migrants were quite abundant throughout the study area. The greatest local abundances of age- 0 ciscoes occurred in the west sector during the period 21-23 August: arctic cisco were captured at every station along the WD transect (Fig. 3) during that period, including some fish found more than $15 \mathrm{~km}$ offshore. Our largest catch of age-0 arctic cisco (226 fish) occurred at a station on the WD transect. Arctic cisco were captured at only two of the 14 stations occupied in the east sector after 31 August. Essentially the entire Dolly Varden catch was obtained at two stations during the early period in 1988. Finally, a few demersal fishes were captured when the sampling gear swept the entire water column at shallow stations.

The small values of the contagion parameter $(k)$ of the negative binomial distribution, as well as power function exponents $(c)$ that exceed 1.0 in all but a single instance, indicate that aggregation prevailed among the more common species (Table 4). Two patterns appear in the $k$ values of the individual species: a systematic increase in each across years and a consistent rank order within years. Capelin were most aggregated (smallest $k$ ), followed by arctic cod, liparids, and arctic cisco. The low exponent value for the 1990 liparid larvae appears to be due to the random occurrence at two stations of replicate catches that were comparatively large and similar in size (50 and 45 fish and 140 and 151 fish, respectively). Tests for goodness of fit of the catch data to the negative binomial distribution gave mixed results. 


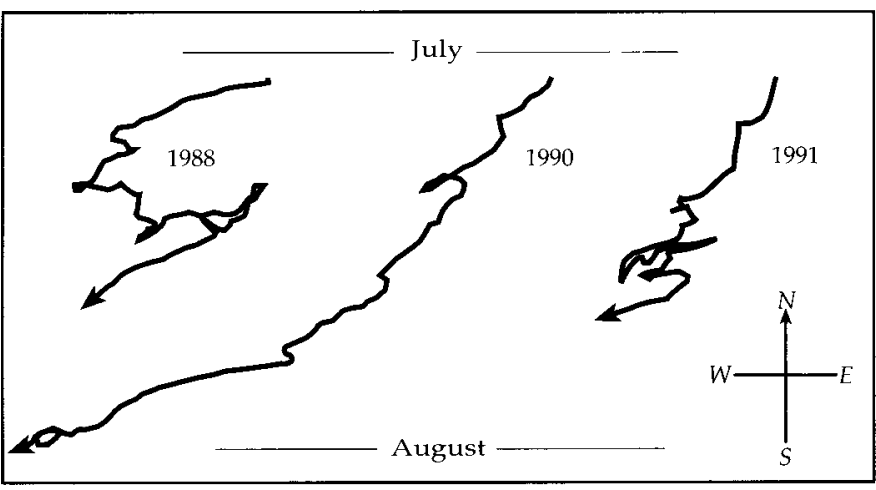

FIG. 4. Progressive vector diagrams of winds at Deadhorse, summers of 1988 and 1990-91. Redrawn from LGL (1994, Fig. 5). Note the consistency in the direction of winds in 1990 as compared to the other years.

\section{Abundance and Density}

In most cases statistical tests were not conducted because of excessive numbers of tied ranks; however, some apparent patterns emerged in the stratified catch data (Table 5). Average arctic cod and capelin CPUEs in the west sector were larger than those in the east sector in all years. The differences appeared greater during the heavy ice years than in the open-water year. Similarly, except for arctic cod in 1988, late period CPUEs consistently exceeded those of the early period. Again, the differences appeared to be greater in heavy ice years. No significant onshore-offshore trends in abundance were detected in arctic cod and arctic cisco CPUEs along the WD transect (Kruskal-Wallis test: pooled 1990-91 arctic cod data; $\mathrm{H}_{\mathrm{c}}=2.63, d f=4, p>0.05 ; 1990$ arctic cisco data, $\mathrm{H}_{\mathrm{c}}=1.72$, $d f=4, p>0.05)$. Large interannual differences in mean densities of fish (Table 6) were similar to those occurring in CPUEs. Densities of all species except capelin declined from 1990 to 1991. Capelin exhibited the opposite trend.

\section{Length, Age, and Growth}

Age-0 arctic cod displayed considerable interannual variability in mean length (Table 7). The lengths of fish in 1990 were significantly greater than those in 1988 (KruskalWallis test: $\mathrm{H}=30.9, d f=2, p<0.001$; multiple comparisons test, $\mathrm{Q}_{\mathrm{c}}=3.31, \mathrm{Q}=5.51$ ), whereas the 1991 lengths did not differ significantly from those in either of the other years $(\mathrm{Q}=1.62$ and 2.11). Also, during the late period in 1990 , fish in the west sector of the study area were on average about $3 \mathrm{~mm}$ longer than those in the east sector; however, the difference was not significant (Mann-Whitney test: $\mathrm{U}$ and $\mathrm{U}^{\prime} \leq 34, \mathrm{U}_{\mathrm{c}}=36$ ). Length frequency distributions of individual samples were typified by several modes. The modes may represent different cohorts produced by spawning and hatching that occurred over a protracted period. The 1990 station data showed considerable scatter in mean lengths on given dates, which also suggests that multiple cohorts of larvae were present. No interannual variation in lengths of age-1 and older arctic cod was evident.

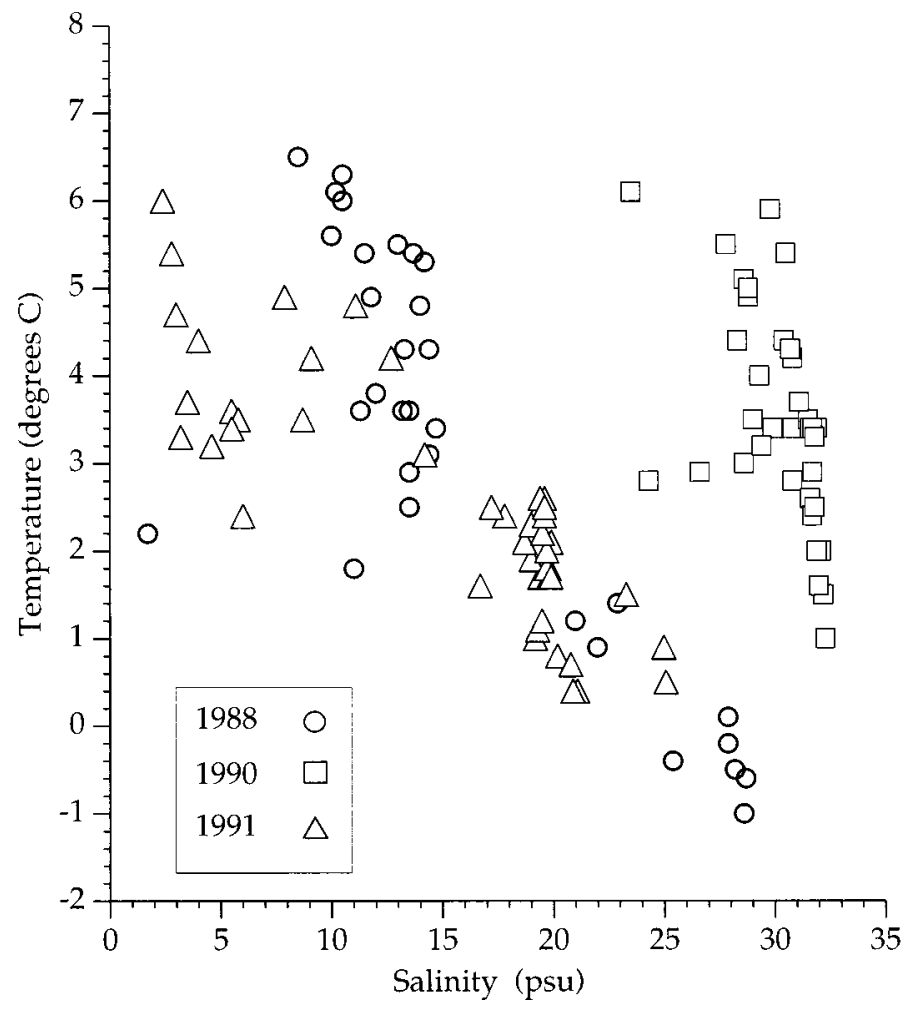

FIG. 5. Surface water temperature-salinity relationships, summers of 1988 and 1990-91. Data shown are 0-2 m averages at stations. The cold $\left(<0^{\circ} \mathrm{C}\right)$, high-salinity values observed in 1988 represent a coastal upwelling event in Camden Bay. Also evident is the relatively high and uniform salinity of surface waters in 1990 as compared to the other two years.

Sufficient data were obtained in 1990 to estimate growth rates of age- 0 arctic cod during late summer; however, the results were inconclusive. A linear regression of average lengths versus dates for the period from 5 August to 5 September produced a growth estimate of $0.4 \mathrm{~mm}$ per day, but the slope of the regression was not significant from zero $\left(\mathrm{N}=7, \mathrm{r}^{2}=0.54, \mathrm{~F}=0.167, p>0.05\right)$. Similar growth rates were suggested by temporal shifts in modes of length frequency distributions.

Capelin displayed little interannual variation in mean length. A test of differences produced a non-significant result (Kruskal-Wallis test: $\mathrm{H}=5.25, d f=2, p>0.05$ ). The capelin catch was dominated by age- 0 fish, but a length range extending to $105 \mathrm{~mm}$ in 1990 indicates that a few age-1 fish may have been included in that year's catch. Length frequency curves for age-0 fish were nearly unimodal, suggesting that a single cohort dominated. With the exception of three 26-29 mm fish captured in 1991, all capelin were over $40 \mathrm{~mm}$ long. Age-0 liparids were significantly larger in 1990 than in either 1988 or 1991 (Kruskal-Wallis test: $\mathrm{H}=12.06, d f=2, p<0.001$ ); multiple comparisons tests: $\mathrm{Q}=14$ and $9.95, \mathrm{Q}_{\mathrm{c}}=1.96$ ). The sizes of fish in the latter two years were not significantly different $(\mathrm{Q}=1.17)$. The majority of arctic cisco were age- 0 fish; however, a few probable age- 1 fish, including two over $100 \mathrm{~mm}$ long, were present. 
TABLE 1 . Statistical summary of area-wide surface (0-2 m average) temperature and salinity by strata, Beaufort Sea study area.

\begin{tabular}{|c|c|c|c|c|c|c|}
\hline \multirow[b]{2}{*}{ Attribute } & \multicolumn{3}{|c|}{ Years } & \multirow[b]{2}{*}{$\mathrm{H}^{2}$} & \multirow[b]{2}{*}{$d f$} & \multirow[b]{2}{*}{$p$} \\
\hline & 1988 & 1990 & 1991 & & & \\
\hline Temperature $\left({ }^{\circ} \mathrm{C}\right)$ & $3.2 \pm 2.3(32)^{1}$ & $3.5 \pm 1.2(37)$ & $2.5 \pm 1.4(47)$ & 9.53 & 2 & $<0.01$ \\
\hline Salinity (psu) & $15.8 \pm 7.0(32)$ & $30.2 \pm 2.1(37)$ & $15.0 \pm 7.0(47)$ & 273.81 & 2 & $<0.001$ \\
\hline \multicolumn{7}{|c|}{ Multiple comparisons results: ${ }^{3}$} \\
\hline Attribute & & Comparison & Q & $\mathrm{Q}_{\mathrm{c}}$ & $\mathrm{H}_{\mathrm{o}}$ : no diff. & \\
\hline \multirow[t]{3}{*}{ Temperature $\left({ }^{\circ} \mathrm{C}\right)$} & & 1991 vs 1990 & 2.932 & 2.394 & Reject & \\
\hline & & 1991 vs 1988 & 0.633 & 2.394 & Accept & \\
\hline & & 1988 vs 1990 & 2.147 & 2.394 & Accept & \\
\hline \multirow[t]{3}{*}{ Salinity (psu) } & & 1990 vs 1988 & 10.346 & 2.394 & Reject & \\
\hline & & 1990 vs 1991 & 11.326 & 2.394 & Reject & \\
\hline & & 1988 vs 1991 & 0.448 & 2.394 & Accept & \\
\hline
\end{tabular}

${ }^{1}$ The stratum mean \pm standard deviation is followed by number of observations in parentheses.

${ }^{2}$ The Kruskal-Wallis test for unequal sample sizes was used to identify significant differences between years, using ranked temperature and salinity data. $\mathrm{H}$ is the test statistic (corrected for ties when necessary); $d f$ is the degrees of freedom; and $p$ the significance of the test, which was determined by comparing $\mathrm{H}$ to critical values of the two-tailed chi-square statistic.

${ }^{3}$ A nonparametric multiple comparisons test was used to locate the significant differences among years. $Q$ and $Q_{c}$ are the test statistic and critical value, respectively, of the test.

\section{Habitat Associations}

Associations of species with particular habitat attributes were not evident in 1990 because surface water property ranges were small and apparently suitable for most species (Table 8). In contrast, the much greater range of salinity in 1991 produced evidence of preference and avoidance (Table 8). Surface waters having salinities of 15 psu or less constituted $42 \%$ of the observations in 1991, yet none of the common species occurred in them. Arctic cod, age- 0 capelin, and liparids showed an apparent affinity for comparatively cool $\left(>1-3^{\circ} \mathrm{C}\right)$, moderately saline $(>15-20$ psu) waters. Species occurrences in the coldest $\left(>0-2^{\circ} \mathrm{C}\right)$, most saline ( $>20 \mathrm{psu}$ ) waters were roughly proportional to the percentage representation of those waters. Some details of habitat use that were lost in the categorization and screening of the 1991 data merit mention. Capelin larvae occurred within a salinity range of 4 to $25 \mathrm{psu}$. Arctic cod were captured only at stations where salinities exceeded 14.2 psu.

\section{DISCUSSION}

\section{Habitat Attributes}

The large interannual, seasonal, and shorter-term variations of surface water properties observed along the Beaufort Sea coast in summer result from the complex interplay of climate, meteorology, riverine freshwater discharge, and oceanographic processes (see, e.g., Gallaway et al., 1991). In summer, the influence of the winds on shallow coastal waters is pervasive. Ice movements, as well as upwelling, mixing, and advective processes, are largely wind-driven. During the years of directionally inconsistent wind (1988 and 1991), pack ice remained close offshore throughout the summer. Surface salinities were generally quite low until late July or early August, then gradually increased as a result of wind mixing and diminishing river runoff. By contrast, the relatively consistent easterly winds during the summer of 1990 forced the pack ice far offshore, fostered vigorous wind mixing, and accelerated the seasonal transition from estuarine to marine conditions. Surface salinities in early August exceeded those reached a month later during the heavy ice years.

Setting aside the biased 1991 results, the surface waters in the east sector of the study area were more "marine-like" than those in the west sector. Because of the interannual variations in wind patterns mentioned above, geographical differences were relatively small in 1990, but more pronounced in 1988. As expected, geographical variations of salinity were greater than those of temperature. Surface salinities reflect local input of freshwater, which differs considerably between sectors, whereas temperature depends more strongly on processes that act with relative uniformity across the entire study area.

The seasonal influence of low surface-water salinities on the occurrence of fishes was most evident in 1991, when very few marine fish were captured before late August. Until then, salinities in the surface waters were below 13 psu and apparently low enough to exclude all but a few euryhaline cottids.

Length analyses from several species suggest that conditions for growth during the summer of 1990 were better than those in the heavy ice years. In the northeastern Chukchi Sea, Gillispie et al. (1997) observed a similar growth pattern in arctic cod during 1990-91 and attributed it to higher water temperatures during the former year. While the mean surface water temperature in our 
TABLE 2. Statistical summary of surface (0-2 m average) temperature and salinity stratified by geographical sector and time period, Beaufort Sea study area.

\begin{tabular}{|c|c|c|c|c|c|c|c|c|c|}
\hline \multirow[b]{2}{*}{ Attribute } & \multirow[b]{2}{*}{ Year } & \multicolumn{2}{|c|}{ Sectors } & \multirow[b]{2}{*}{ U or U' } & \multirow[b]{2}{*}{$\mathrm{U}_{\mathrm{c}}^{2}$} & \multicolumn{2}{|c|}{ Periods } & \multirow[b]{2}{*}{ U or U' } & \multirow[b]{2}{*}{$\mathrm{U}_{\mathrm{c}}$} \\
\hline & & East & West & & & Early & Late & & \\
\hline \multirow[t]{3}{*}{ Temperature $\left({ }^{\circ} \mathrm{C}\right)$} & 1988 & $2.1 \pm 2.9(13)^{1}$ & $3.9 \pm 1.5(19)$ & 166 & 175 & $4.6 \pm 1.2(21)$ & $0.4 \pm 1.1(11)$ & 231 & 166 \\
\hline & 1990 & $3.0 \pm 1.1(22)$ & $4.2 \pm 1.0(15)$ & 207 & 229 & $4.4 \pm 0.9(10)$ & $3.2 \pm 1.1(27)$ & 204.5 & 193 \\
\hline & 1991 & $4.1 \pm 1.0(13)$ & $2.0 \pm 1.0(34)$ & 404 & 304 & $4.1 \pm 0.9(16)$ & $1.8 \pm 0.7(31)$ & 488.5 & 336 \\
\hline \multirow[t]{3}{*}{ Salinity (psu) } & 1988 & $20.6 \pm 8.0$ & $12.6 \pm 3.6(19)$ & 180 & 175 & $12.5 \pm 1.8(21)$ & $22.3 \pm 8.6(11)$ & 294 & 166 \\
\hline & 1990 & $31.3 \pm 0.9(22)$ & $28.6 \pm 2.4(15)$ & 289 & 229 & $29.1 \pm 2.2(10)$ & $30.5 \pm 2.0(27)$ & 200.5 & 193 \\
\hline & 1991 & $5.1 \pm 2.3$ & $18.8 \pm 3.6(34)$ & 388.5 & 304 & $6.0 \pm 3.1(16)$ & $19.7 \pm 2.1(31)$ & 496 & 336 \\
\hline
\end{tabular}

${ }^{1}$ Stratum means \pm standard deviations are followed by number of observations in parentheses.

${ }^{2}$ Results of Mann-Whitney U tests on ranked temperature and salinity data are shown. All tests were two-tailed with a significance level of 0.05. $U$ and $U$ ' are the test statistics, the larger of which is shown. If either exceeds the critical value $U_{c}$, a significant difference is present.

study area also was higher in 1990 than in 1991, we suspect that the dominant easterly winds during the former year may have been the ultimate influence on fish growth through their overreaching effects on a variety of proximate environmental factors, including food availability as well as temperature.

\section{Catch Data}

The negative binomial distribution appears to be a suitable statistical descriptor of catch patterns of common epipelagic fishes in the study area. Biological interpretation of the contagion parameter of the negative binomial distribution is not straightforward, because it varies with species, life history stage, sampling effort, and sampling gear (Welch and Ishida, 1993). Rapid changes of $k$ are especially evident during the early life histories of many pelagic fishes. The consistency of within-year rank orders of species' $k$ values in our results suggests the presence of species-specific differences in aggregation, while the systematic increases of individual species' $k$ values across years appear to be an effort effect. The relatively high normalized $k$ value for arctic cod in 1988, as compared to those for the following years, can be interpreted as a size effect produced by differing selectivities of sampling gears. The 1988 seine catch was dominated by age- 1 and older fish. The inconsistency of the goodness-of-fit test results may stem from our use of the chi-square procedure instead of an available parametric test (described in Poole, 1974) that requires relatively complex computations. The chisquare tests suffered from losses of degrees of freedom arising from numerous zero catches and pooling of frequency classes, a problem also experienced by Jahn (1987). Finally, both Poole (1974) and Hilborn and Mangel (1997) note that the chi-square statistic can be distorted by chance irregularities.

Our indices of age- 0 fish abundances (expressed as CPUE) are lower, and our estimates of mean lengths higher, than actual population values because of extrusion or escape of smaller individuals through the net meshes.
The seine data are the most biased, as demonstrated by comparison with tow net catch data obtained in the Prudhoe Bay area during 1988 (Houghton and Whitmus, 1988). Age-0 fish composed only $12 \%$ of arctic cod captured by the seine, whereas that age group represented $95 \%$ of the species' catch and the second highest species CPUE in the tow net results. Age-0 liparids also were well represented in the 1988 tow net catch, while the seine captured none. A more representative sampling of the entire size spectrum of the common fish larvae in the study area would entail the concurrent use of $505 \mathrm{~mm}$ mesh nets, which capture arctic cod and liparids as small as $5 \mathrm{~mm}$ (Tarbox and Moulton, 1980) and capelin as small as $3.86 \mathrm{~mm}$ (Norcross and Frandsen, 1996).

The offshore abundances of Dolly Varden and age-1 and older arctic cisco in the study area are probably most accurately reflected by Houghton and Whitmus' (1988) tow net CPUEs and our seine CPUEs, both of which averaged about one fish per station. Large $(100-400 \mathrm{~mm})$ fish appear to have avoided our tow net (towed at $0.5 \mathrm{~m} \cdot \mathrm{sec}^{-1}$ ), whereas the $1 \mathrm{~m} \cdot \mathrm{sec}^{-1}$ tow speed used by Houghton and Whitmus was sufficient to capture them.

\section{Features of the Epipelagic Fish Community}

Our study shows that the surface waters between the Colville River and Barter Island are quite uniform with respect to fish species richness and composition. Fish appear to be somewhat more abundant in the lagoon habitat than in the open coastal habitat. It is also evident that both occurrence and abundance of species vary dramatically in time and space in response to changing hydrographic conditions. Thus, while we captured few marine fishes in the east sector of the study area in 1991, they may have been present below the reach of our tow net. Using a combination of trawling and hydroacoustic surveys in the Prudhoe Bay area, Moulton and Tarbox (1987) showed that when a brackish surface layer is present, marine fish associate primarily with the underlying transition layer between it and marine water. 
TABLE 3. Catch summary, Beaufort Sea study area, 1988 and 1990-91. Sampling was by purse seine in 1988 and by surface tow net in $1990-91$.

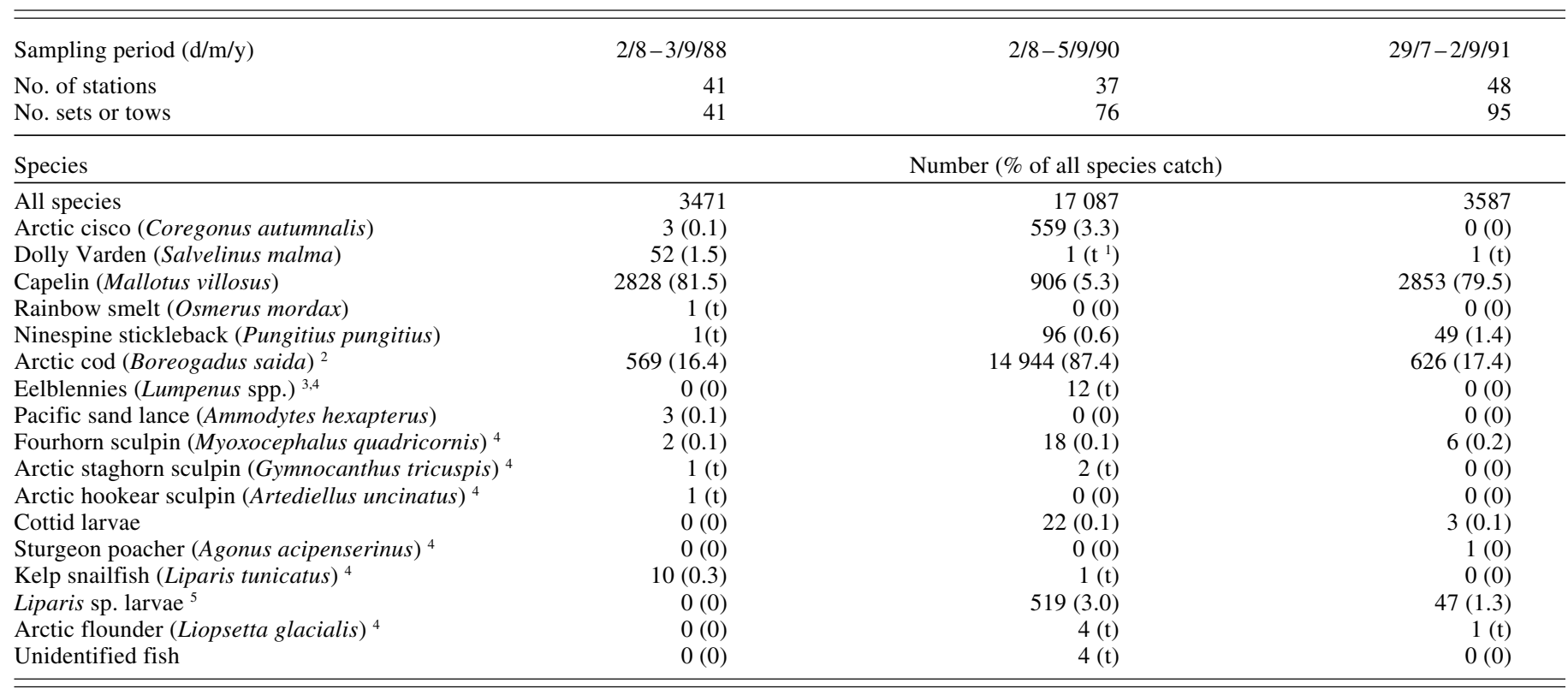

${ }^{1}$ Trace amount of $<0.1 \%$.

${ }^{2}$ May include a small percentage of saffron cod (Eleginus gracilis). See Methods section.

${ }^{3}$ Identified as slender and stout eelblennies (Lumpenus fabricii and L. medius, respectively).

${ }^{4}$ Presumably demersal fishes.

${ }^{5}$ Probably L. gibbus and/or L. fabricii. See Methods section.

The epipelagic fish community in the study area appears to represent a transition between those of adjacent regions. Diadromous freshwater species richness is higher than that of the northeastern Chukchi Sea, where freshwater fishes are virtually absent because the area lacks large rivers (Fechhelm et al., 1984). Conversely, to the east along the Yukon coast, diadromous freshwater species richness probably attains its highest level in the North American Arctic because of the expansive brackish water habitat produced by the Mackenzie River, the largest river in the North American Arctic (see Kendel et al., 1975). The species richness of the marine component of the coastal fish community is lower in the study area than in the northeastern Chukchi Sea, which includes Bering Sea species (Echeverria et al., 1997); but it is probably greater than in the Yukon coastal waters, where low salinity prevails.

\section{Marine Species}

Arctic Cod: Mean densities of age- 0 arctic cod in the surface waters during 1990 and 1991 were within the range of previously reported late summer-fall values, both within the study area and elsewhere in the North American Arctic. In the Prudhoe Bay area, estimated densities were $14.2 \cdot 1000 \mathrm{~m}^{-3}$ in 1979 (Tarbox and Moulton, 1980) and $15.5 \cdot 1000 \mathrm{~m}^{-3}$ in 1988 (Houghton and Whitmus, 1988). In Simpson Lagoon, monthly mean surface densities ranged between 0 and $82 \cdot 1000 \mathrm{~m}^{-3}$ in 1977 and 1978 (Craig and
Griffiths, 1978; Craig et al., 1982). In the Lancaster SoundBaffin Bay region of the eastern Canadian Arctic, estimated densities of age- 0 arctic cod were 7.3 and $31.1 \cdot 1000 \mathrm{~m}^{-3}$ in 1976 and 1978, respectively (Sekerak, 1982; Table 3). The last-noted value is the most comparable to ours, because it too is based on samples from a large geographical area. Much higher local densities occasionally occur when arctic cod form large aggregations (Craig et al., 1982; Sekerak, 1982; Welch et al., 1993). The apparent decrease in arctic cod abundance in the study area between 1990 and 1991 was echoed by a similar, albeit less dramatic, decrease in the northeastern Chukchi Sea during the same period (Gillispie et al., 1997).

Craig et al. (1982) and others demonstrated a general seasonal pattern of increasing arctic cod abundance inshore that is linked to the progressive salinization of the brackish water. Offshore sampling has provided more information about that pattern. A habitat use study conducted by Cannon et al. (1991) in the Prudhoe Bay area showed that arctic cod were most abundant at intermediate salinities $(10-20 \mathrm{psu})$, water temperatures $\left(4-10^{\circ} \mathrm{C}\right)$, and depths. The results of our study suggest that arctic cod avoid waters having salinities below 14 psu.

Arctic cod display considerable interannual and geographical variation in growth. In the study area, mean lengths attained by age- 0 arctic cod by late August or early September have ranged from 11 to $42 \mathrm{~mm}$ (Tarbox and Moulton, 1980; Craig et al., 1982; Houghton and Whitmus, 1988; this study). By comparison, mean lengths reported 
TABLE 4. 1988 and 1990-91 catch statistics for common species, Beaufort Sea study area.

\begin{tabular}{|c|c|c|c|c|c|c|c|}
\hline Year & Species & Frequency of occurrence at stations & CPUE Mean ${ }^{1}$ & CPUE Range $^{1}$ & $c^{2}$ & $k^{3}$ & $k_{1}^{4}$ \\
\hline \multirow[t]{2}{*}{1988} & Capelin & $5 / 41$ & 69.0 & $0-1801$ & - & $0.014^{5}$ & 0.00034 \\
\hline & Arctic cod & $17 / 41$ & 13.9 & $0-307$ & - & $0.093^{6}$ & 0.00227 \\
\hline \multirow[t]{4}{*}{1990} & Arctic cod & $28 / 37$ & 196.6 & $0-3418$ & 1.027 & $0.123^{5}$ & 0.00162 \\
\hline & Capelin & $10 / 37$ & 11.9 & $0-522$ & 1.572 & 0.036 & 0.00047 \\
\hline & Arctic cisco & $18 / 37$ & 7.4 & $0-154$ & 1.187 & 0.128 & 0.00169 \\
\hline & Liparid larvae & $19 / 37$ & 6.8 & $0-151$ & 0.871 & $0.125^{5}$ & 0.0016 \\
\hline \multirow[t]{3}{*}{1991} & Capelin & $19 / 48$ & 30.0 & $0-945$ & 1.715 & $0.058^{5}$ & 0.00061 \\
\hline & Arctic cod & $26 / 48$ & 6.6 & $0-111$ & 1.027 & 0.171 & 0.00180 \\
\hline & Liparid larvae & $14 / 48$ & 0.5 & $0-10$ & 1.027 & 0.230 & 0.00242 \\
\hline
\end{tabular}

${ }^{1}$ Catch-per-unit-effort (CPUE) data are from 41 purse seine sets in 1988 and 171 surface tow net sets, 76 in 1990 and 95 in 1991.

${ }^{2}$ The quantity $c$ is the exponent of the power function $s^{2}=a \cdot m^{c}$, in which $s^{2}$ is the sample variance, $m$ the sample mean, and $c$ and $a$ are constants. It was estimated by linear regression of log-transformed data from replicate tows. A $c>1$ indicates extra-Poisson variation in the data. No estimates of $c$ are available for 1988 as replicates were not taken that year.

${ }^{3} \mathrm{~K}$ is the contagion parameter of the negative binomial distribution; it was estimated by a maximum likelihood procedure.

${ }^{4} K_{1}$ is $k$ normalized to one unit of effort to allow comparisons among years.

${ }^{5}$ Chi-square goodness-of-fit test for fit to negative binomial distribution rejected at $\alpha=0.05, d f=f-3$.

${ }^{6}$ Chi-square test not possible as $d f=0$.

from various Canadian arctic and subarctic locations ranged from 17 to $27 \mathrm{~mm}$ (Sekerak, 1982: Fig. 9). The size attained by age- 0 arctic cod in the study area during 1990 thus appears to be an exceptional occurrence. The larvae were more than $30 \mathrm{~mm}$ long by 5 August, which suggests that hatching took place earlier than usual and that prey resources were superabundant throughout the summer. A paucity of length samples from the early period and a large amount of scatter in the data stemming from the presence of multiple size cohorts rendered our regression estimate of growth rates of age-0 fish during 1990 inconclusive. Significant decreases in mean lengths of age- 3 and younger arctic cod in the northeastern Chukchi Sea between 1990 and 1991 (Gillispie et al., 1997) parallel our observations of age- 0 arctic cod in those years. Perhaps the concordance reflects climatic influences extending across northern Alaska.

Capelin: The Beaufort Sea coastal waters appear to be an important habitat for age- 0 capelin throughout the summer, whereas older fish seem to be present for comparatively brief periods during spawning runs. Fyke net catch patterns in the study area typically consist of zero or trace capelin catches punctuated by rare large catches. The large catches have consisted of adult fish (U.S. Fish and Wildlife Service, Fairbanks, AK 99701, unpublished data; W. Wilson, LGL, Anchorage, AK, pers. comm. 1996) and probably represent beach spawning events, which have been observed in July and August elsewhere in the Beaufort and Chukchi Seas (Kendel et al., 1975; Bendock, 1977; Fechhelm et al., 1984). Available information suggests multiple spawning events may occur during summer in the study area. On the basis of size at age $(\approx 65 \mathrm{~mm}$ at 90 d; Leggett and Frank, 1990), our capelin catches appeared to be composed mainly of fish from a June spawning. A second spawning may occur in July, as evidenced by observations of larvae less than $10.5 \mathrm{~mm}$ long in July (noted in Houghton and Whitmus, 1988) and less than $30 \mathrm{~mm}$ long in late August (Houghton and Whitmus, 1988; this study). A third spawning may occur in August. Over 10000 capelin were captured in fyke nets at Camden Bay during early August 1990 (U.S. Fish and Wildlife Service, Fairbanks, AK 99701, unpublished data). Length measurements show that the catch consisted mostly of age-2 and age- 3 fish. Presumably they were spawners.

Little interannual variation in mean lengths of age- 0 capelin was evident during the three years of this study (Houghton and Whitmus, 1988; this study). Perhaps prey availability is less variable for capelin than it is for arctic cod. An alternative explanation, noted by Leggett and Frank (1990), is that capelin are more efficient foragers than arctic cod. Finally, the size attained in late summer by the presumptive June cohort of capelin seems exceptionally large (Houghton and Whitmus, 1988; this study): it is similar to that of age- 1 fish in the St. Lawrence estuary and western Gulf of St. Lawrence (Bailey et al., 1977).

Liparids: Age-0 liparids, associated primarily with relatively saline marine water, are fairly abundant in the epipelagic fish community. Densities of age-0 liparids observed in the study area vary widely (Tarbox and Moulton, 1980; Houghton and Whitmus, 1988; this study); in general, they are significantly higher near the bottom than at the sea surface when low-salinity surface water is present (Tarbox and Moulton, 1980). The occurrence of small $(5 \mathrm{~mm})$ liparid larvae in the plankton from late July through late August (Tarbox and Moulton, 1980) indicates that certain species-presumably L. gibbus and L. fabriciihave an extended summer spawning and hatching period. Liparid larvae captured in the Prudhoe Bay area during summer may have originated from spawning at the "Boulder Patch" in Stefansson Sound, where during late winter 
TABLE 5. Summary of catches of common fishes stratified by geographical area and time period, Beaufort Sea study area.

\begin{tabular}{|c|c|c|c|c|c|c|c|c|c|}
\hline \multirow[b]{2}{*}{ Species } & \multirow[b]{2}{*}{ Year } & \multicolumn{2}{|c|}{ Sectors } & \multirow[b]{2}{*}{ U or U' } & \multirow[b]{2}{*}{$\mathrm{U}_{\mathrm{c}}{ }^{2}$} & \multicolumn{2}{|c|}{ Periods } & \multirow[b]{2}{*}{$\mathrm{U}$ or $\mathrm{U}^{\prime}$} & \multirow[b]{2}{*}{$\mathrm{U}_{\mathrm{c}}$} \\
\hline & & East & West & & & Early & Late & & \\
\hline Arctic cod & $\begin{array}{l}1988 \\
1990 \\
1991\end{array}$ & $\begin{array}{c}2.4(16)^{1} \\
197.4(21) \\
0 \quad(15)\end{array}$ & $\begin{array}{r}21.3(25) \\
206.0(16) \\
8.2(33)\end{array}$ & $\begin{array}{c}- \\
177 \\
-\end{array}$ & $\begin{array}{c}- \\
233 \\
-\end{array}$ & $\begin{array}{c}17.5(27) \\
44.0(10) \\
0.03(18)\end{array}$ & $\begin{array}{r}7.1(14) \\
259.2(27) \\
12.0(30)\end{array}$ & $\begin{array}{c}- \\
224 \\
-\end{array}$ & $\begin{array}{c}- \\
193 \\
-\end{array}$ \\
\hline Capelin & $\begin{array}{l}1988 \\
1990 \\
1991\end{array}$ & $\begin{array}{r}41.9(16) \\
3.4(21) \\
0.3(15)\end{array}$ & $\begin{array}{l}86.2(25) \\
23.8(16) \\
41.8(33)\end{array}$ & $\begin{array}{l}- \\
- \\
-\end{array}$ & $\begin{array}{l}- \\
- \\
-\end{array}$ & $\begin{array}{l}0.1(27) \\
0.4(10) \\
0.2(18)\end{array}$ & $\begin{array}{r}201.8(14) \\
16.6(27) \\
46.2(30)\end{array}$ & $\begin{array}{l}- \\
- \\
-\end{array}$ & $\begin{array}{l}- \\
- \\
-\end{array}$ \\
\hline Liparids & 1990 & $8.5(21)$ & $4.7(16)$ & - & - & $0.4(10)$ & $9.3(27)$ & - & - \\
\hline Arctic cisco & 1990 & $1.0(21)$ & $15.2(16)$ & - & - & $0.4(10)$ & $9.5(27)$ & - & - \\
\hline
\end{tabular}

${ }^{1}$ Grand means of mean station catches are shown, followed by numbers of observations in parentheses.

${ }^{2}$ Mann-Whitney U tests were used to test differences between strata, using station means as ranking data. Tests were two-tailed at a significance level of 0.05 . $U$ and $U$ ' are test statistics, the larger of which is shown. If either $U$ or $U$ ' exceeds the critical value $U_{c}$, a significant difference is present. Few tests were possible because of excessive numbers of tied ranks. See text for explanation.

divers have observed adult kelp snailfish, adhesive eggs on kelp fronds and hard substrates, and planktonic larvae that appeared to be liparids (Dunton et al., 1982). Our capture of a large number of liparid larvae at a station in the east sector of the study area suggests spawning habitat is also present there.

Other Marine Fishes: Considerable offshore sampling effort has produced only one large catch of larval cottids in the study area-a somewhat unexpected result given the abundance and ubiquity of fourhorn sculpin in the region. Available information (Kendel et al., 1975; Tarbox and Moulton, 1980; Houghton and Whitmus, 1988) suggests that larval fourhorn sculpin occur primarily in very shallow inshore waters. Larvae of arctic flounder, another common inshore marine species, also appear to be rare or absent from the surface waters of the study area during summer.

Diadromous Freshwater Fishes: The sparse available data indicate that Dolly Varden and age- 1 and older arctic cisco are the most widely distributed species in the study area and that their offshore densities are very low (Craig et al.,1985; Houghton and Whitmus, 1988; Fruge et al., 1989; Palmer and Dugan, 1990; Underwood et al., 1992; this study).

Significant new information on age- 0 arctic cisco migration patterns was acquired in 1990. While limited to a single year's observations, our data suggest that the age- 0 arctic cisco's migratory corridor can extend offshore beyond the brackish water zone. The vigor and apparent good condition of fish captured offshore indicate that they were acclimated and not individuals "lost to the population." The easterly winds that aid the migration of age- 0 arctic cisco across the study area (Gallaway et al., 1983; Fechhelm and Fissel, 1988; Fechhelm and Griffiths, 1990; Schmidt et al., 1991) also foster coastal upwelling and mixing, which increase salinity in the surface waters. During 1990, comparatively high-salinity water prevailed at most stations where arctic cisco occurred. Laboratory experiments (Fechhelm et al., 1991; Fechhelm et al., 1993) have demonstrated the ability of age- 1 to age- 4 arctic cisco to
TABLE 6. Annual mean densities of fish in the $0-2 \mathrm{~m}$ depth interval, Beaufort Sea study area, 1990-91.

\begin{tabular}{lcc}
\hline \hline Year & 1990 & 1991 \\
\hline Number of tows & 76 & 95 \\
Volume filtered $\left(\mathrm{m}^{3}\right)$ & 295510 & 349820 \\
\hline Species & \multicolumn{2}{c}{ Densities $\left(\mathrm{no}^{\circ} \cdot 1000 \mathrm{~m}^{-3}\right)^{1}$} \\
\cline { 2 - 3 } All & 57.8 & 10.3 \\
Arctic cod & 50.6 & 1.8 \\
Capelin & 3.1 & 8.2 \\
Liparids $^{2}$ & 1.8 & 0.1 \\
Arctic cisco $^{2}$ & 1.9 & 0 \\
\hline \hline
\end{tabular}

${ }^{1}$ Means are based on the number of tow net catches divided by total volume filtered each summer.

${ }^{2}$ Age-0 fish.

tolerate high salinities, which supports the notion that little, if any, mortality occurs when the arctic cisco encounter high salinities in nature. Indeed, such tolerance may be viewed as a key adaptation that allows the species to migrate successfully across the region.

\section{Patterns and Processes}

Physical processes strongly influence the structure and function of the marine ecosystem in Alaska's Beaufort Sea coastal region. A study of trophic dynamics led Craig et al. (1984) to conclude that the ecological succession in Simpson Lagoon is maintained at an early stage because of the prevailing high level of habitat disturbance. This conclusion appears applicable to the entire coastal region. More particularly, the epipelagic fish community is affected by those physical processes that affect the ambient thermohaline regime and prey availability.

The alternating numerical dominances of larval capelin and arctic cod observed in the study area may be a manifestation of differing biological responses to wind-driven hydrographic processes. The pattern appears comparable to that in eastern Canadian waters, where it has been shown 
TABLE 7. Length statistics for common epipelagic fishes, Beaufort Sea study area.

\begin{tabular}{|c|c|c|c|c|c|c|c|}
\hline \multirow[b]{2}{*}{ Species } & \multirow[b]{2}{*}{ Age } & \multirow[b]{2}{*}{ Year } & \multicolumn{3}{|c|}{ Fork length $(\mathrm{mm})$} & \multirow[b]{2}{*}{$\mathrm{N}^{1}$} & \multirow[b]{2}{*}{ Source $^{2}$} \\
\hline & & & Mean & SD & Range & & \\
\hline \multirow[t]{8}{*}{ Arctic cod } & 0 & 1988 & 26 & 2 & $22-32$ & 57 & $1^{3}$ \\
\hline & & & 24 & 3 & $12-36$ & 1020 & $2^{4}$ \\
\hline & & 1990 & 42 & 6 & $21-59$ & 1492 & 1 \\
\hline & & 1991 & 29 & 5 & $12-58$ & 440 & 1 \\
\hline & $\geq 1$ & 1988 & 83 & 10 & $61-143$ & 436 & 1 \\
\hline & & & 90 & 15 & $55-172$ & 304 & 2 \\
\hline & & 1990 & 87 & 15 & $60-167$ & 318 & 1 \\
\hline & & 1991 & 78 & 15 & $60-133$ & 56 & 1 \\
\hline \multirow[t]{4}{*}{ Capelin } & 0 & 1988 & 62 & 8 & $40-80$ & 542 & 1 \\
\hline & & & 61 & 7 & $28-82$ & 480 & 2 \\
\hline & & 1990 & 64 & 12 & $41-105$ & 183 & 1 \\
\hline & & 1991 & 62 & 5 & $26-76$ & 1086 & 1 \\
\hline \multirow[t]{3}{*}{ Liparids } & 0 & 1988 & 18 & 3 & $10-28$ & 135 & 2 \\
\hline & & 1990 & 26 & 4 & $17-41$ & 72 & 1 \\
\hline & & 1991 & 18 & 3 & $10-29$ & 43 & 1 \\
\hline Arctic cisco & 0 & 1990 & 77 & 9 & $51-123$ & 559 & 1 \\
\hline
\end{tabular}

${ }^{1} \mathrm{~N}$ is the aggregate number of measurements.

${ }^{2}$ Selected tow net data from another study are included to illustrate effects of gear selectivity on our 1988 results, which were obtained by seine sampling, and to provide a consistent basis for among-year comparisons.

${ }^{3}$ This study.

${ }^{4}$ From Houghton and Whitmus (1988, Table 3).

that wind influences the survival of capelin larvae: more survive in years when onshore winds hold warm water inshore, and fewer survive in years when offshore winds cause upwelling (Leggett et al., 1984; Leggett and Frank, 1990). In the former conditions, survival is enhanced by a combination of retention of larvae in warm, brackish water, the presence of suitable prey, and fewer predators. Conversely, during upwelling conditions, capelin larvae are carried offshore, as well as being exposed to more predation and competition for food when increased salinities and lowered temperatures afford access to cod and other species. When capelin larvae are not abundant, arctic cod numbers increase-a result of greater prey availability in the absence of competition from capelin.

The prevalent easterly winds may be the agent ultimately responsible for the notable growth of larval arctic cod and liparids in 1990. We speculate that the following conditions led to rapid growth: (1) the easterly wind drove the sea ice far offshore comparatively early in the summer, thereby enhancing nutrient supply and regeneration in the surface waters due to increased wind mixing and upwelling; (2) the absence of shading by ice increased primary production rates; (3) the relatively early onset of production and the increased water volume in which the production occurred produced a greater net annual primary production; (4) the effects of the above cascaded to secondary production, supplying abundant prey-especially copepod nauplii-for consumers such as larval fish; and (5) the
TABLE 8. Species-habitat associations, Beaufort Sea study area, 1990-91, using species occurrence data from 32 tow net samples.

\begin{tabular}{|c|c|c|c|c|c|c|}
\hline \multicolumn{3}{|c|}{ Habitat attributes ${ }^{1}$} & \multicolumn{4}{|c|}{ No. of Species Occurrences } \\
\hline $\begin{array}{c}\mathrm{T} \\
\left({ }^{\circ} \mathrm{C}\right)\end{array}$ & $\begin{array}{c}\mathrm{S} \\
(\mathrm{psu})\end{array}$ & $\begin{array}{c}\text { No. of } \\
\text { Occurrences }\end{array}$ & $\begin{array}{l}\text { Arctic } \\
\text { cod }\end{array}$ & Capelin ${ }^{2}$ & Liparids $^{2}$ & $\begin{array}{l}\text { Arctic } \\
\text { cisco }^{2}\end{array}$ \\
\hline \multicolumn{7}{|l|}{1990} \\
\hline$>6-7$ & $>20-25$ & 1 & 0 & 1 & 1 & 1 \\
\hline$>5-6$ & $>25-30$ & 3 & 2 & 1 & 0 & 2 \\
\hline$>4-5$ & $>25-30$ & 1 & 1 & 0 & 0 & 1 \\
\hline$>3-4$ & $>25-30$ & 3 & 1 & 1 & 3 & 1 \\
\hline$>2-3$ & $>25-30$ & 1 & 1 & 0 & 0 & 0 \\
\hline$>5-6$ & $>30-35$ & 1 & 1 & 0 & 1 & 1 \\
\hline$>4-5$ & $>30-35$ & 3 & 3 & 2 & 1 & 2 \\
\hline$>3-4$ & $>30-35$ & 8 & 7 & 3 & 5 & 5 \\
\hline$>2-3$ & $>30-35$ & 6 & 4 & 0 & 3 & 1 \\
\hline$>1-2$ & $>30-35$ & 4 & 3 & 0 & 2 & 0 \\
\hline$>0-1$ & $>30-35$ & 1 & 1 & 0 & 0 & 0 \\
\hline \multicolumn{7}{|l|}{1991} \\
\hline$>5-6$ & $>0-5$ & 3 & 0 & 0 & 0 & 0 \\
\hline$>4-5$ & $>0-5$ & 1 & 0 & 0 & 0 & 0 \\
\hline$>3-4$ & $>0-5$ & 3 & 0 & 0 & 0 & 0 \\
\hline$>3-4$ & $>5-10$ & 4 & 0 & 0 & 0 & 0 \\
\hline$>2-3$ & $>5-10$ & 1 & 0 & 0 & 0 & 0 \\
\hline$>4-5$ & $>10-15$ & 2 & 0 & 0 & 0 & 0 \\
\hline$>2-3$ & $>15-20$ & 7 & 6 & 2 & 2 & 0 \\
\hline$>1-2$ & $>15-20$ & 9 & 8 & 7 & 4 & 0 \\
\hline$>0-1$ & $>15-20$ & 1 & 1 & 0 & 1 & 0 \\
\hline$>0-1$ & $>20-25$ & 2 & 2 & 1 & 1 & 0 \\
\hline$>0-1$ & $>25-30$ & 1 & 1 & 0 & 1 & 0 \\
\hline
\end{tabular}

${ }^{1}$ Temperature and salinity data are $0-2 \mathrm{~m}$ averages. Only stations at which temperatures and salinities varied by less than $0.5^{\circ} \mathrm{C}$ and $0.5 \mathrm{psu}$ in the $0-2 \mathrm{~m}$ depth interval aree included.

${ }^{2}$ Age-0 fish.

relatively early erosion of the brackish water band broadened the "window of opportunity" for the marine species, allowing them more prolonged access to abundant prey resources than in the heavy ice years, when stratification persisted longer along the coast.

While no measurements of primary and secondary production are available to confirm the above hypothesis, some indirect evidence is available. Underwood et al. (1997) observed significant interannual differences in condition of Dolly Varden in the ANWR area during the same three years: condition was highest in 1990, followed by 1988 and 1991. Similarly, Fechhelm et al. (1996) found arctic cisco collected in the Prudhoe Bay area during late summer 1988 and 1990 were significantly heavier than those collected during early summer, whereas in 1991 there was no significant difference in their condition between those periods.

\section{ACKNOWLEDGEMENTS}

This study was conducted while the authors were affiliated with the Office of Ocean Resources Conservation and Assessment of the National Oceanic and Atmospheric Administration (NOAA) in Anchorage, Alaska. R. Baxter (deceased), J. Hanson (Environmental Protection Agency), and B. Mahoney (National Marine Fisheries 
Service) assisted us in the field. From our office, J. Dermody, G. Lapiene, and NOAA Corps officers Lt. M. Eagleton and Lt. Comdr. P. Harmon, were responsible for logistics and vessel operations and assisted in data collection. S. Close, D. Friis, D. Hale, and G. York participated in field work, computer programming, and data reduction. V. Elliot, R. Fechhelm, K. Holland, L. Holland-Bartels, L. Moulton, and T. Underwood provided helpful comments on the initial draft manuscript. Finally, we acknowledge the reviews of three referees, whose comments and suggestions markedly improved this document. Funding support for the study was provided by the Minerals Management Service (MMS), U.S. Department of the Interior, through an Interagency Agreement with NOAA, as part of the MMS Environmental Studies Program. The Western Regional Office of the U.S. Geological Survey/Biological Resource Division provided funds for the preparation of this paper.

\section{REFERENCES}

ABLE, K.W. 1990. A revision of arctic snailfishes of the genus Liparis (Scorpaeniformes: Cyclopteridae). Copeia:476-492.

ABLE, K.W., FAHAY, M.P., and MARKLE, D.F. 1986. Development of larval snailfishes (Pisces: Cyclopteridae: Liparidinae) from the western North Atlantic. Canadian Journal of Zoology 64:2294-2316.

BAILEY, R.F.J., ABLE, K.W., and LEGGETT, W.C. 1977. Seasonal and vertical distribution and growth of juvenile and adult capelin (Mallotus villosus) in the St. Lawrence estuary and western Gulf of St. Lawrence. Journal of the Fisheries Research Board of Canada 34:2030-2040.

BENDOCK, T.N. 1977. Beaufort Sea estuarine fish study. In: Environmental Assessment of the Alaskan Continental Shelf. Final reports, biological studies. Vol. 4. U.S. Department of Commerce, National Oceanic and Atmospheric Administration; U.S. Department of the Interior, Minerals Management Service. 1979. Unpubl. ms. available from National Technical Information Service, Springfield, Virginia 22161, U.S.A. 670-729.

CANNON, T.C., GLASS, D.R., and PREWITT, C.M. 1991. Habitat use patterns of juvenile arctic cod in the coastal Beaufort Sea near Prudhoe Bay, Alaska. In: Benner, C.S., and Middleton, R.W., eds. Fisheries and oil development on the continental shelf. Bethesda, Maryland: American Fisheries Society. 157-162.

CRAIG, P.C. 1984. Fish use of coastal waters of the Alaskan Beaufort Sea: A review. Transactions of the American Fisheries Society 113:265-282.

CRAIG, P.C., and GRIFFITHS, W. 1978. Beaufort Sea barrier island-lagoon ecological process studies. III. Ecology of fishes in Simpson Lagoon, 1977. In: Environmental Assessment of the Alaskan Continental Shelf. Annual Reports of Principal Investigators. Vol. 7. U.S. Department of Commerce, National Oceanic and Atmospheric Administration; U.S. Department of the Interior, Minerals Management Service. Unpubl. report available from National Technical Information Service, Springfield, Virginia 22161, U.S.A. 587-664.

CRAIG, P.C., GRIFFITHS, W.B., HALDORSON, L., and McELDERRY, H. 1982. Ecological studies of arctic cod (Boreogadus saida) in Beaufort Sea coastal waters, Alaska.
Canadian Journal of Fisheries and Aquatic Sciences 39:395406.

CRAIG, P.C., GRIFFITHS, W.B., JOHNSON, S.R., and SCHELL, D.M. 1984. Trophic dynamics in an arctic lagoon. In: Barnes, P.W., Schell, D.M., and Reimnitz, E., eds. The Alaskan Beaufort Sea: Ecosystems and environments. New York: Academic Press. 347-380.

CRAIG, P.C., GRIFFITHS, W.B., HALDORSON, L., and McELDERRY, H. 1985. Distributional patterns of fishes in an Alaskan arctic lagoon. Polar Biology 4:9-18.

DUNN, J.R., and VINTER, B.M. 1984. Development of larvae of the saffron cod, Eleginus gracilis, with comments on the identification of gadid larvae in Pacific and Arctic waters contiguous to Canada and Alaska. Canadian Journal of Fisheries and Aquatic Sciences 41:304-318.

DUNTON, K., RIEMNITZ, E., and SCHONBERG, S. 1982. An arctic kelp community in the Alaskan Beaufort Sea. Arctic 35:465-484.

ECHEVERRIA, T.W., BARBER, W.E., and ECHEVERRIA, S.W. 1997. Water masses and transport of age- 0 arctic cod and age-0 Bering flounder into the northeastern Chukchi Sea. In: Reynolds, J.B., ed. Fish ecology in arctic North America. Bethesda, Maryland: American Fisheries Society. 60-67.

FECHHELM, R.G., and FISSEL, D. 1988. Wind-aided recruitment of Canadian arctic cisco (Coregonus autumnalis) into Alaskan waters. Canadian Journal of Fisheries and Aquatic Sciences 45:906-910.

FECHHELM, R.G., and GRIFFITHS, W.B. 1990. Effect of wind on the recruitment of Canadian arctic cisco (Coregonus autumnalis) into the central Alaskan Beaufort Sea. Canadian Journal of Fisheries and Aquatic Sciences 47:2164-2171.

FECHHELM, R.G., CRAIG, P.C., BAKER, J.S., and GALLAWAY, B.J. 1984. Fish distribution and use of nearshore waters in the northeastern Chukchi Sea. Prepared for National Oceanic and Atmospheric Administration by LGL Ecological Research Associates, Inc., 1410 Cavitt Street, Bryan, Texas 77801. Unpubl. report available from National Technical Information Service, Springfield, Virginia 22161, U.S.A.

FECHHELM, R.G., FECHHELM, J.D., HERLUGSON, C.J., and BEAUBIEN, D.K. 1991. Bioassay tests of acute temperature and salinity shock to arctic cisco. In: Benner, C.S., and Middleton, R.W., eds. Fisheries and oil development on the continental shelf. Bethesda, Maryland: American Fisheries Society. 109-118.

FECHHELM, R.G., FITZGERALD, P.S., BRYAN, J.D., and GALLAWAY, B.J. 1993. Effect of salinity and temperature on the growth of yearling arctic cisco (Coregonus autumnalis) of the Alaskan Beaufort Sea. Journal of Fish Biology 43:463-474.

FECHHELM, R.G., GRIFFITHS, W.B., MARTIN, L.R., and GALLAWAY, B.G. 1996. Intra- and interannual variation in the relative condition and proximate body composition of arctic ciscoes from the Prudhoe Bay region of Alaska. In: Reynolds, J.B., ed. Fish ecology in arctic North America. Bethesda, Maryland: American Fisheries Society. 600-612.

FRUGE, D.J., WISWAR, D.W., DUGAN, L.J., and PALMER, D.E. 1989. Fish population characteristics of Arctic National Wildlife Refuge coastal waters, summer 1988. U.S. Fish and Wildlife Service Progress Report. Unpubl. report available from 
U. S. Fish and Wildlife Service, 101 12th Avenue, Box 17, Room 222, Fairbanks, Alaska 99701, U.S.A.

GALLAWAY, B.J., GAZEY, W.J., CRAIG, P., and HELMRICKS, J. 1983. An assessment of the Colville River delta stock of arctic cisco (Coregonus autumnalis): Migrants from Canada? Biological Papers of the University of Alaska 21:4-23.

GALLAWAY, B.J., GAZEY, W.J., COLONELL, J.M., NIEDORODA, A.W., and HERLUGSON, C.J. 1991. The Endicott Development Project: Preliminary assessment of impacts from the first major offshore oil development in the Alaskan Arctic. In: Benner, C.S., and Middleton, R.W., eds. Fisheries and oil development on the continental shelf. Bethesda, Maryland: American Fisheries Society. 42-80.

GILLISPIE, J.G., SMITH, R.L., BARBOUR, E., and BARBER, W.E. 1997. Distribution, abundance, and growth of arctic cod in the northeastern Chukchi Sea. In: Reynolds, J.B., ed. Fish ecology in arctic North America. Bethesda, Maryland: American Fisheries Society. 81-89.

HELSEL, D.R. 1990. Less than obvious: Statistical treatment of data below the detection limit. Environmental Science and Technology 24:1766-1774.

HILBORN, R., and MANGEL, M. 1997. The ecological detective: Confronting models with data. Princeton, New Jersey: Princeton University Press.

HOUGHTON, J.P., and WHITMUS, C.J. 1988. Shallow neritic fish of the central Beaufort Sea. Report prepared for Standard Alaska Production Company by Dames \& Moore, 500 Market Place Tower, 2025 First Avenue, Seattle, WA 98121, U.S.A. Available from Lyman Thorsteinson, United States Geological Survey, 909 First Avenue, Suite 800, Seattle, WA 98121, U.S.A.

JAHN, A.E. 1987. Precision of estimates of abundance of coastal fish larvae. Bethesda, Maryland: American Fisheries Society Symposium 2:30-38.

KENDEL, R.E., JOHNSON, A.C., LOBSIGER, U., and KOZAK, M.D. 1975. Fishes of the Yukon coast. Beaufort Sea Technical Report No. 6, Beaufort Sea Project, Department of the Environment, 512 Federal Building, 1230 Government St., Victoria, British Columbia V8W 1Y4, Canada.

LEGGETT, W.C., and FRANK, K.T. 1990. The spawning of the capelin. Scientific American 262:102-107.

LEGGETT, W.C., FRANK, K.T., and CARSCADDEN, J.E. 1984. Meteorological and hydrographic regulation of year-class strength in capelin (Mallotus villosus). Canadian Journal of Fisheries and Aquatic Sciences 41:1193-1201.

LGL. 1994. The 1992 Endicott Development fish monitoring program. Final report. Volume. I: Analysis of fyke net data. Prepared for BP Exploration (Alaska) Inc. and North Slope Borough by LGL Alaska Research Associates, Inc. Unpubl. report available from BP Exploration (Alaska) Inc., Environmental and Regulatory Affairs Department, P.O. Box 196612, Anchorage, Alaska 99519-6612, U.S.A.

MANGEL, M. 1987. Sampling highly aggregated populations with application to California sardine management. Springer lecture notes in biomathematics. Springer-Verlag 72:247-263.

MOULTON, L.L., and TARBOX, K.E. 1987. Analysis of arctic cod movements in the Beaufort Sea nearshore region, 1978-79. Arctic 40:43-49.
NORCROSS, B.L., and FRANDSEN, M. 1996. Distribution and abundance of larval fishes in Prince William Sound, Alaska, during 1989 after the Exxon Valdez oil spill. In: Rice, S.D., Spies, R.B., Wolfe, D.A., and Wright, B.A., eds. Proceedings of the Exxon Valdez Oil Spill Symposium. Bethesda, Maryland: American Fisheries Society. 463-486.

PALMER, D.E., and DUGAN, L.J. 1990. Fish population characteristics of Arctic National Wildlife Refuge coastal waters, summer 1989. U.S. Fish and Wildlife Service, Progress Report, Fairbanks, Alaska. Unpubl. report available from U.S. Fish and Wildlife Service, 101 12th Avenue, Box 17, Room 222, Fairbanks, Alaska 99701, U.S.A.

POOLE, R.W. 1974. An introduction to quantitative ecology. New York: McGraw-Hill.

SCHMIDT, D.R., GRIFFITHS, W.B., BEAUBIEN, D.K., and HERLUGSON, C.J. 1991. Movement of young-of-the-year arctic ciscoes across the Beaufort Sea coast. In: Benner, C.S., and Middleton, R.W., eds. Fisheries and oil development on the continental shelf. Bethesda, Maryland: American Fisheries Society. $132-144$.

SEKERAK, A.D. 1982. Young-of-the-year cod (Boreogadus) in Lancaster Sound and western Baffin Bay. Arctic 35:75-87.

TARBOX, K., and MOULTON, L. 1980. Larval fish abundance in the Beaufort Sea near Prudhoe Bay, Alaska. Prepared for Prudhoe Bay Unit by Woodward-Clyde Consultants. Unpubl. report available from Environmental Department, ARCO Alaska, Inc., P.O. Box 360, Anchorage, Alaska 99510, U.S.A.

UNDERWOOD, T.J., GORDON, J.A., and OSBORNE, B.M. 1992. Fish population characteristics of Arctic National Wildlife Refuge coastal waters, summer 1990. U.S. Fish and Wildlife Service, Alaska Fisheries Progress Report No. 92-03. Unpubl. report available from U.S. Fish and Wildlife Service, 101 12th Avenue, Box 17, Room 222, Fairbanks, AK 99701, U.S.A.

UNDERWOOD, T.J., GORDON, J.A., MILLARD, M.J., THORPE, L.A., and OSBORNE, B.M. 1995. Characteristics of selected fish populations of Arctic National Wildlife Refuge coastal waters, final report, 1988-91. U.S. Fish and Wildlife Service, Fairbanks Fishery Resource Office, Alaska Fisheries Technical Report No. 28, Fairbanks, AK. Unpubl. report available from U.S. Fish and Wildlife Service, 101 12th Avenue, Box 17, Room 222, Fairbanks, Alaska 99701, U.S.A.

UNDERWOOD, T.J., PALMER, D.E., THORPE, L.A., and OSBORNE, B.M. 1997. Weight-length relationships and condition of Dolly Varden in coastal waters of the Arctic National Wildlife Refuge, Alaska. In: Reynolds, J.B, ed. Fish ecology in arctic North America. Bethesda, Maryland: American Fisheries Society. 295-309.

WELCH, D.W., and ISHIDA, Y. 1993. On the statistical distribution of salmon in the sea: Application of the negative binomial distribution, and the influence of sampling effort. Canadian Journal of Fisheries and Aquatic Sciences 50:1029-1038.

WELCH, H.E., CRAWFORD, R.E., and HOP, H. 1993. Occurrence of arctic cod (Boreogadus saida) schools and their vulnerability to predation in the Canadian High Arctic. Arctic 46:331-339.

ZAR, J.H. 1996. Biostatistical analysis. 3rd ed. Englewood Cliffs, New Jersey: Prentice-Hall, Inc. 